\section{RECORDS OF LEITH'S SOFT SHELL TURTLE, AsPIDERETES LEITHI (GRAY, 1872) AND ASIAN GIANT SOFT SHELL TURTLE, PELOCHELYS CANTORII (GRAY, 1864) IN BHARATHAPUZHA RIVER, KERALA}

\section{A. Biju Kumar}

Department of Zoology, N.S.S. College, Ottapalayam, Palakkad, Kerala 679103, India.

Email:abiju@rediffmail.com

with web supplement

The trionychid turtles (Testudines: Trionychidae) in Indian subcontinent are represented by five genera, namely, Lissemys, Pelochelys, Chitra, Dogania and Trionyx (currently Aspideretes) (Sharma, 1998). Two species of Trionychid turtles, the Leith's Softshell Turtle (Aspideretes leithi (Gray, 1872) and Asian Giant Softshell Turtle Pelochelys cantorii (Gray, 1864) were collected from Bharathapuzha, the longest river in Kerala State.

Endemic to peninsular India, Aspideretes leithi has been recorded from various states of India such as Madhya Pradesh, Maharastra, Karnataka, Andhra Pradesh, Orissa and Tamil Nadu (Smith, 1931; Daniel, 1983; Tikader \& Sharma, 1985; Kalaiarasan et al., 1992; Das, 1995; Sharma, 1998). From Kerala Thomas et al. (1997) reported this species from Chaliyar River. The present record extends the known range of the species further south in Kerala. Three specimens of Aspideretes leithi were obtained from Koottilakkadavu, Koodalloor region (the meeting place between Thoothapuzha and Bharathapuzha rivers). All the specimens were adults measuring 24.4, 30.6 and $38.5 \mathrm{~cm}$ respectively in length, and $16.2,20.4$ and $29.0 \mathrm{~cm}$ respectively in width. The dorsal surface of the body was olive green with lighter vermiculation, while the ventral part was yellowish-white. All the specimens were obtained from a professional turtle hunter in the region. The professional turtle hunters (mainly fishermen) dive into the pools of the river with a spear, locate the turtle down in water, and pierce the spear into the carapace in order to collect the turtles. The turtles are then tied with a rope on their legs (Image $1^{w}$ ) till they are delivered to the local markets or toddy (liquor made from coconut) shops.

Aspideretes leithi is currently a threatened species on account of over exploitation for their flesh and eggs (Sharma, 1998). Anecdotal evidences confirm that each turtle hunter used to collect up to 10 turtles during 'season' (February-May, when the water level in the river goes down considerably during summer), and depending on size, each turtle is sold at a rate of Rs. 100-300. According to the turtle hunters, off late, there is a considerable decline in accessible population and some days they do not get even a single specimen. None of the turtle hunters or local fishermen were aware that the species was endangered. It is important to note that Koottilakkadavu is the only region in Bharathapuzha River from which Aspideretes leithi was collected by the author during the biodiversity survey of the river (March 1998 - December 2000). This demands immediate regulation of their fishing in the river and awareness programmes on the need for conserving this species of turtle among the local population and fishermen.

The Asian Giant Softshell Turtle Pelochelys cantorii (Image $2^{\mathrm{w}}$ ), distributed in India, Malaysia, Laos, South China, Philippines, Indonesia, Myanmar, Thailand, Vietnam and Singapore, is a little known species from India, with dwindling populations (Das, 1995). During the biodiversity survey of the Bharathapuzha River a dead specimen of this species was collected from the sandy banks of the Ponnani Estuary $\left(10^{\circ} 46^{\prime}-\right.$ $10^{\circ} 48^{\prime} \mathrm{N} \& 75^{0} 54^{\prime}-75^{0} 56^{\prime} \mathrm{E}$ ) where the Bharathapuzha River empties into the Lakshadweep Sea. The specimen was olive green in colour dorsally and pale yellow ventrally. Its length was $58 \mathrm{~cm}$ and width $52.2 \mathrm{~cm}$. From the Kerala coast, Pelochelys cantorii has been recorded from Thiruvananthapuram towards south (Nair \& Badrudeen, 1975) and from Mangavadu, Valapattanam River, towards the north (Palot \& Radhakrishnan, 2002). Further, it is now considered that Jerdon's (1853) record of Gynopus indicus from Mahe Estuary along the southwest coast of India may actually be Pelochelys cantorii (Webb, 1981). This indicates that, although uncommon, this species enjoys a distribution all along the Kerala coast. However, absence of data and records coupled with rarity in habitats handicap framing any definite conclusion.

\section{REFERENCES}

Daniel, J.C. (1983). The Book of Indian Reptiles. Bombay Natural History Society, Mumbai, $141 \mathrm{pp}$.

Das, I. (1995). Turtles and Tortoises of India. Oxford University Press, Bombay, 176pp.

Jerdon, T.C. (1853). Catalogue of reptiles inhabiting the peninsula of India. Journal of the Asiatic Society of Bengal 22: 462-479.

Kalaiarasan, V., R. Kanakasabai and N. Rathinasabapathy (1992). Record of the riverine turtle Trionyx leithi from Tanjavur District, Tamil Nadu. Journal of the Bombay Natural History Society 89(2): 258-259.

Nair, P.V.R. and M. Badrudeen (1975). On the occurrence of the Softshell Turtle, Pelochelys bibroni (Owen) in marine environment. Indian Journal of Fisheries 22: 270-274.

Palot, M.J. and C. Radhakrishnan (2002). Occurrence of Asian Giant Softshell Turtle, Pelochelys cantorii (Gray, 1864) in Northern Kerala. Zoos' Print Journal 17(4): 770.

Sharma, R.C. (1998). Fauna of India - Reptilia (Testudinea and Crocodilia). Vol. I, xvi+196pp.

Smith, M.A. (1931). The Fauna of British India, including Ceylon and Burma. Reptilia and Amphibia: Vol. 1. Loricata, Testudines. Taylor and Francis, London xxviii+170pp.

Thomas, J., C.P. Shaji and P.S. Easa (1997). Record of Leith's Softshell Turtle, Aspideretes leithi (Gray), (Family Trionychidae) from Nilambur, Kerala. Journal of the Bombay Natural History Society 94: 580.

Tikader, B.K. and R.C. Sharma (1985). Handbook - Indian Testudines. Zoological Survey of India, Calcutta, 156pp.

Webb, R.G. (1981). The Narrow-headed Softshell Turtle, Chitra indica (Testudines: Trionychidae), in peninsular India. Records of the Zoological Survey of India 79: 203-204.

\section{ACKNOWLEDGEMENT}

The author is thankful to the Southern Regional Office, University Grants Commission, Bangalore for providing financial support to carry out the project. Thanks are due to N.S.S. management and Principal and Head, Department of Zoology, N.S.S. College, Ottapalayam for providing the infrastructure facilities to carry out the work.

" See Images 1 \& 2 on the web at www.zoosprint.org 